\title{
Immigranteak EAE-ra etortzeko faktoreak eta arrazoiak. Zein dei-faktoreri buruz ari gara?
}

\author{
Factors and reasons of immigratory afluence to the BAC. \\ What «effects called» do we talk about?
}

Amaia Garcia-Azpuru • amaia.garcia@camarabilbaoubs.com

CÁMARA BILBAO UNIVERSITY BUSINESS SCHOOL

Angeriñe Elorriaga Illera · angeriñe.elorriaga@ehu.eus

EUSKAL HERRIKO UNIBERTSITATEA

Recibido: 16/10/2017

Aceptado: $21 / 11 / 2017$

\section{Laburpena}

Lan honetan, Euskadirako immigrazioa azaltzen duten faktoreak eta arrazoiak aztertzen dira, gizarte-laguntzak horietako bat ote diren egiaztatu ahal izateko.

Xede horrekin, ikerketa enpirikoa planteatu dugu, izaera kuantitatiboa eta kualitatiboa dituena aldi berean. Estatistika ofizialetatik ateratako datuekin batera, adituen ezagutzak konbinatu dira. Alde batetik, alderdi kuantitatiboan, Euskal Autonomia Erkidegoan dauden atzerritarrei buruzko informazioa eta EAEn eta Espainiako gainerako lurraldeetan dauden atzerritar kopurua alderatu ditugu. Beste alde batetik, alderdi kualitatiboan, nazioarteko migrazio-fluxuen arloan adituek diotena jaso dugu.

Lortutako emaitzei erreparatuz, EAEn immigranteen kopuruak gora egin du duela bi hamarkadatik. Hala ere, immigrante potentzialentzat ez da jomugako erkidegoetako bat, EAE Estatuko batezbestekoaren azpitik baitago kopuru absolutuetan zein ehunekoetan. Horrez gain, egindako elkarrizketen emaitzak ere kontuan hartu ditugu. Beraz, esandako guztia dela eta, alde batera utzi behar dugu ohiko diskurtsoa, hots, Diru-sarrerak Bermatzeko Errenta (DBE) eta beste gizarte-laguntza batzu- direla-eta erkidegora immigrazioa etortzea sustatzen dela. Horren ordez, beste faktore edo arrazoi batzuk aipatu behar dira, besteak beste, lan-harremanak eta jomugan aurretik finkatuta dauden gizarte-sareak. Nolabait esanda, gizarteak hautatu behar du bi hauen artean: komunikabideek eta talde politikoek immigrazioa jomugako gizarte-laguntzei lotuta dagoela erakusten duten errealitatea eta eskaintzen diren lan-aukerei erreparatzen dien immigrazioaren errealitatea.

Hitz-gakoak: Immigrazioa; gizarte-laguntzak, etortzeko faktoreak; lan-merkatua; Euskadi.

\section{Abstract}

The scope of this article is the factors and reasons that explain the immigration to the Basque Country, in order to verify if it is the social aid one of them.

To aim this, a combined empirical quantitative and qualitative research has been proposed, allowing to cross data contributed by the official statistics with expert knowledge. Thus, the quantitative part would provide information on the presence of foreigners in the Basque Autonomous Community (BAC) and its comparison with the rest of Spain; and the qualitative part would contribute to all the existing expert knowledge in the matter of international migratory flows.

The results obtained show an increase of immigrant presence in the BAC for the last two decades, but this is far from being a community claim for the potential immigrant, because the position below the national average in absolute and percentage terms; and with the results of the interviews carried out, make it possible to 
Immigranteak EAE-ra etortzeko faktoreak eta arrazoiak | Amaia Garcia-Azpuru, Angeriñe Elorriaga Illera

overturn the usual discourse in which the income Welfare Benefits (WB) —and another series of social aidsencourages the arrival of immigration to the community, giving way to another series of factors or reasons of arrival such as job opportunities and social networks already settled in destination. Somehow, society is in the dilemma between a reality presented by the mass media or the political class where immigration is almost always linked to social assistance at destination, and the reality of an immigration that attends the employment opportunities offered.

Key words: Immigration; social aids, arrival factors; labor market, Basque Country. 


\section{SARRERA}

(...) langileak eta immigranteak iristean, aldaketak gertatzen ziren gizarte-egituran eta herritarren kultura-osaeran. (...)

Askoz geroago, duela hamarkada bi baino gutxiago, gure hiri eta herrietako kaleetan bestelako jendea zegoela nabaritzen hasi ginen. Kostaldera adineko jendea iritsi zen, ilehoriak, bertakoekin ia-ia harremanik ez zutenak eta sorlekuko hizkuntza soilik hitz egiten zutenak. Europako erretirodun eta errentadunen ostean, pertsona gazteagoak iritsi ziren, gaztelaniaz hitz egiten zuten, baina sorlekuko herrialdeetako askotariko azentuekin: erbesteratu latinoamerikarrak ziren, eta geroko immigrazio ekonomikoaren ateak ireki zituzten. Haien agerpena nabarmena izan zen Espainiako geografiako zenbait puntutan, batez ere Madrilen, Bartzelonan eta Levanteko kostaldean. Baina askoz deigarriagoa izan zen bertako fenotipotik argi eta garbi bereizten ziren ezaugarri fisikoak zituzten pertsonak agertzea: asiarrak, arabiarrak eta beltzak plaza, garraiobide publiko eta eskualde batzuetako landetan agertzen hasi ziren. Urte luzeetan emigrantea izandako Espainia atzerriko immigranteen hartzaile bihurtzen ari zen. [...]

(Colectivo Ioé - Inmigrantes, Trabajadores, ciudadanos, 1998:4)

Horrela hasten zen Colectivo IOÉk 1998an egindako Inmigrantes, Trabajadores, Ciudadanos txostena. Txosten horrek berri-berria dirudi gaur egun, joan den mendeko laurogeita hamarreko hamarkadaren amaieran idatzita egon arren. Izan ere, gaur egun oraindik nazioarteko immigrazioaren fenomenoa asimilatzen ari dira Espainian.

Azken hamarkadetan Espainiara orokorrean eta Euskal Autonomia Erkidegora (EAE) zehazki immigrazioa etorri denez, helmugako herrialdeko migrazio-fluxuak lotu edo zehazten dituzten faktoreak zein diren planteatu izan da.

Pertsonen fluxu horiek arlo politikotik zein gizarte-arlotik interesa eta kezka pizten dituzte, bai berriak direlako, bai errealitate berria ezagutzen ez delako. Izan ere, azken urteetan aztertutako datuen arabera, ezarpen-errealitatea da, a priori pentsa daitekeena baino askoz arrazionalagoa.

Teoria asko ahalegindu dira azaltzen sorleku eta jatorri desberdinetako pertsonak sorlekutik atera eta jomugara iristera bultzatzen duten arrazoiak eta faktoreak. Komunikabideek ere ideia asko ematen dizkiete herritarrei horren inguruan. Baina, askotan, ideia horiek ez daukate inolako zerikusirik immigrazio-gertaeraren errealitatearekin.

Beraz, gizarte-kolektibo «berri» baten aurrean gaude, eta gero eta garrantzi gehiago dauka bai nazioan bai autonomia-erkidegoetan. Euskal Autonomia Erkidegoa ez dago lehen to- 
kietan immigrante ${ }^{1}$ egoiliarren bolumenari dagokionez, baina gero eta nabarmenagoa da kolektibo hori bertako biztaneen artean. Hori dela eta, garrantzitsua da ulertzen ahalegintzea zein diren pertsona horiek EAEra iristea azaltzeko faktoreak. Arrazoi horiek ulertzen direnean hartu ahal izango dira erabaki zuzenak arlo politiko-legaletik, gero eta aniztunagoa eta heterogeneoagoa den gizartearen elkarbizitzari mesede egiteko.

Ohikoa da entzun edo irakurtzea EAEn kokatuta dagoen immigrazioa eta askotariko eta gehiegizko gizarte-prestazioak lotuta daudela. Komunikabideetatik atera eta gizartean zabaltzen diren datuok zurrumurruen giroa eragiten dute eta arrazakeriari edo xenofobiari lotutako jokabideak agerrarazten dituzte. Horixe da Diru-sarrerak Bermatzeko Errentaren $(\mathrm{DBE})^{2}$ kasua. Prestazio ekonomiko hori, askotan, immigranteen kolektiboak gehiegi erabiltzen duela esan ohi da, eta erkidegora gero eta immigrante gehiago erakartzeko faktore nagusitzat hartzen da. Hala ere, datu kuantitatibo zein kualitatiboen errealitatea ikusita, teoria hori hankaz gora jarri behar da.

Migrazio-fluxuak eta euskal errealitatea ezagutzen dituzten adituei egindako analisi kualitatiboan irizpideak bat datoz esatean osagai hori, DBE —edo bestelako gizarte-laguntzak-, ez dela euskal lurraldera immigrazioa iristearen funtsezko arrazoia. Bestalde, datu estatistikoei erreparatuz, Euskal Autonomia Erkidegoko immigrazio-ehunekoak Estatuko batezbestekoaren azpitik daude atzerritar egoiliarren bolumenaren ikuspuntutik (termino absolutuetan) zein euskal gizartearen barruan duten ordezkaritzaren ikuspuntutik (immigranteen dentsitate demografikoa). Modu horretan, behin betiko alde batera uzten dugu autonomia-erkidego honetara immigrazioa etortzeko funtsezko arrazoia DBE dela dioen ideia.

Gizarte-laguntzak Euskadira immigranteak etortzeko faktore erabakigarria ez direla ezarri ondoren, fluxuen portaera azaltzeko beste arrazoi batzuk aipa ditzakegu. Faktore horiek migrazio-fluxuen eraginkortasuna azaltzean aipatzen dira, baina, hala ere, komunikabideek ez dituzte kontuan hartzen. Azken horiek DBE aipatzen dute azken urteetan fluxu horiek azaltzeko orduan. Komunikabideek aprobetxatzen dute bertako biztanleen artean immigrazioari lotutako iritzi sendorik ez dagoela, eta, horrela, ezaugarri zehatzak dituen iritzia finkatzen laguntzen dute, eta gizartea, zeharka, komunikabide eta/edo politikarien interesen arabera bideratzen dute, ez errealitatea kontuan hartuta (Garcia Azpuru, 2016).

Puntu honetan ikusten genuen beharrezkoa EAEra immigranteak etortzearen faktoreak eta/edo arrazoiak aztertzea. Hori dela eta, analisi hori hartu dugu abiapuntu.

\footnotetext{
${ }^{1}$ Artikulu osoan, nazioarteko immigrazioari egingo diogu aipamen, nahiz eta guk erabiliko dugun terminoa «immigrazioa» izan.

${ }^{2}$ DBEri buruzko informazio gehiago lortzeko: http://www.euskadi.eus/gobierno-vasco/contenidos/ayuda_ subvencion/1201/es_5401/es_18720.html, http://www.lanbide.euskadi.eus/rgi//informacion/que-es-la-rgi/
} 


\section{ESPARRU TEORIKOA}

Nazioarteko migrazioa egon badagoenez, aztertu egin behar da zein diren migrazioproiektu bat abiatzeko erabaki indibidual eta kolektibo horien atzean dauden arrazoiak. Modu horretan, gizabanako baten migratzeko erabakian eraginik handiena duten faktoreei buruzko zenbait teoria daude.

Teoria asko daude atzerritar jatorriko immigranteen kolektiboak jomugara iristea azaltzen ahalegintzen direnak. Hala ere, horietako batek ere ez dio erantzuten gizarte hartzaileetan askotan sortzen diren zergatien eta zalantzen multzo zabalari.

Migrazioei buruzko azterketa teorikoen jatorria Ravensteinek ikuspuntu soziodemografiko eta ekonomikotik xix. mendearen amaieran egindako analisiak dira, mikro zein makro mailan. Geografo horrek migrazioen arrazoiei buruzko printzipio edo lege batzuk ezarri zituen, eta migrazio-fluxuen jatorriak eta jomugak lotu zituen, migrazio-prozesuetan dauden erregulartasun batzuen behaketa oinarri hartuta (Arango, 1985). Ravensteinen ustez, migrazio-mugimenduen motorra eskualdeen arteko aldeak ziren, errenta mailari eta enplegu bolumenari zegokienez, baita lan-indarraren lurralde-banaketa desegokia ere. Horrela hasi ziren hitz egiten erakarpen eta aldarapen faktoreei edo push eta pull faktoreei buruz. Faktore horiek Ravensteinek (1885) emandako zerrendan jaso ziren. Bere ustez, emigratzeko erabakiak erantzun ahal zien jatorrian eragiten duten faktoreei zein jomugan eragiten duten faktoreei, edo bien konbinazioari. Ravensteinen «hamabi legeak» migrazioetan zenbait erregulartasun enpiriko orokortu eta aurreikusteko lehen ahalegina dira, eta migrazio-fenomenoaren azalpen-esparru osoa ezartzen dute. Migrazioak merkatuko sistema kapitalistak eta eskaintza eta eskariaren legeek behartutako mugimendu moduan ulertzen dira.

Une horretatik aurrera, Push-Pull teoria esparru teoriko neoklasikoan garatzen da, eta horren barruan, garai hartako ekonomia politikoaren oinarrizko parametroak arrazionalismoa, indibidualismoa eta liberalismoa ziren. Beraz, migrazio-proiektu bat hasteko erabakia hartzen da gizabanako bakoitzak migrazioaren kostuen-onuren inguruan egiten duen analisia oinarri hartuta. Kontuan hartzen da a priori faktore batzuk daudela sorlekua uztera behartzen dutenak (push), beste leku batzuetan dauden baldintza mesedegarriagoekin alderatzen direlako; baldintza horiek erakarpen indarra egiten dute (pull), eta horien konbinazioa kanporatze dinamikaren (push) eta erakarpen dinamikaren (pull) erantzulea da. Push faktoreen artean, nabarmentzekoak dira herritarren segurtasunik eza edo zaurgarritasun sozial, ekonomiko eta politikoa. Kasu askotan, faktore horiek erabakigarriak dira migrazio-proiektu bat abiatzeko orduan. Modu berean, bi leku/herrialderen arteko errenten artean dagoen aldea faktore motor edo erabakigarri moduan hartzen da, ez bakarrik sorlekutik ateratzea azaltzeko, baita jomuga zehatz batera iristea azaltzeko ere.

Bada, gizabanakoak, askatasun osoz, aukera guztiak haztatzen ditu, eta erabaki bat hartzen du une horretan nagusi den pentsamendu ekonomikoaren arrazionaltasuna oina- 
rri hartuta. Nolanahi ere, merkatuetan eragiten duten agenteen askatasuna oinarri duen teoria hau ez da gai erantzuteko merkatuetan sortzen diren arazoei, eta gainera, zenbait paradoxa sor ditzake, hala nola Hollifieldek (1992) migrazio-fluxuei dagokienez enuntziatutakoa, hots, «paradoxa liberala» deitutakoa. Paradoxa horrek erakusten du liberalismoaren logika ekonomikoak eskatzen duela mugak irekitzea alde batetik, egon dauden laneskuaren beharrizanak direla-eta, baina, beste alde batetik, logika politiko eta legalak mugak ixtea eskatzen duela. Gizarte-esparruan, paradoxa hori honela laburtuko litzateke: immigranteak behar ditugu, baina ez zaizkigu gustatzen.

Modu horretan, teoria klasikoek migrazioaren gaiari buruz emandako azalpenetan zeuden hutsuneak zirela-eta, ordura arte ia-ia zalantzan jartzen ez zena berrikusi eta kritikatu zen, eta pentsamendu-ildo berriak agertu ziren. Horiek nazioarteko migrazio-fluxuen arrazoiak planteatu zituzten berriro ere, eta horietako batek ere berez zergatia azaltzen ez duen arren, jomugako herrialde baten barruan, fluxuek jomuga batzuk edo beste batzuk hautatzen dituzte, eta arrazoi bat beste guztien gainetik gailentzen da. Puntu honetan, Lan Merkatuaren Segmentazioren Teoriek (LMST) eta, zehatzago esanda, Doeringer-ek eta Piorek (1985) landutako Lanaren Merkatu Dualaren Teoriak, Lan Merkatuaren Segmentazioaren Teoria ere deituak (TSMT) ${ }^{3}$, gainerako teoriek utzitako argi-ilunak argi ditzake.

Lan merkatuaren segmentazioaren teoria horiek azpimarratzen dute lan-merkatua arautzeko antolaketa-faktoreek eta faktore instituzionalek ere eragina dutela eta lan-indarraren barruan heterogeneotasun kualitatiboa dagoela. Azken horrek oinarri objektiboa izan dezake, edo enplegu-emailearen iritzi baten emaitza interesatua izan daiteke. Horien artean, Lanaren Merkatu Dualaren Teoria (LMDT ere deitua) da jomugako atzerritarren immigrazioaren lurralde-banaketa gehien argitzen duena, lan-merkatuaren segmentazioa aztertzen baitu.

Teoria horren oinarrizko ideia da lan-merkatua bi segmentu desberdinetan bereizten dela. Lehenengo segmentua lehen mailako sektorea edo merkatua da, eta bigarrena, bigarren mailako sektorea edo merkatua. Merkatuaren segmentazio hori egiteko, lanpostuaren baldintzak eta ezaugarriak hartzen dira oinarri. Enplegu horiek mailakatzen dira hauen arabera: alokairuak, enpresaren edo erakundearen barruko bermeak eta sustapen perspektibak, eskatutako kualifikazio profesionalen batez besteko maila, lan baldintzak eta giroa, etab. Langileak, era berean, enpresaren barruan mailakatzen dira hauen arabera: autonomia eta erantzukizun maila, enplegu horretan duten antzinatasuna, enplegu horren alokairu bidezko aitorpena, emandako eta lortutako prestakuntza maila, gaitasunak, produktibitate eta kalitate handiagoa lortzeko konpromiso maila, etab. Horren guztiaren eraginez, alde nabarmena sortzen da lehen mailako merkatuaren eta bigarren mailako merkatuaren artean.

\footnotetext{
3 Doeringer eta Pioreren Lanaren Merkatu Dualaren Teorian lan-merkatua segmentu bereizietan zatitzeak duen garrantzia dela-eta, askotan, teoria hori Segmentazioaren Teoria moduan hartzen da, baina benetan, segmentazioaren beste teoria bat da.
} 
Lehen mailako merkatuak bigarren mailakoetatik bereizten dira egonkortasuna, lanaren eta enpleguaren kalitate handiagoa eta zuzeneko eta zeharkako ordainsarien maila direla eta. Bestela esanda, lehen mailako merkatuetan nagusi dira enplegu egonkorra, soldata handiagoak, lan-baldintza onak, sustapen-aukerak, ekitate handiagoa, lan arloko legeen administrazioari dagokionez aldez aurretik ezarritako prozedurekin; hau da, aipatutako faktoreak modu mesedegarrian ebaluatzen dira. Hala ere, lehen mailako merkatu horren barruan, bereizketa dago erdi mailako langileen eta langile klaseko langileen artean: lehenengoak lehen mailako merkatuaren goiko segmentuan kokatuta daude, eta bigarrenak, lehen mailako merkatuaren beheko segmentuan. Piorek lehen mailako merkatuaren barruan bereizketa hori egiten du, eta, beraz, beheko geruza eta goiko geruza egongo lirateke, ezaugarri desberdinekin. Beheko geruzako ezaugarriak bigarren mailako merkatuaren ezaugarrietatik hurbil egongo lirateke, eta goiko geruzako ezaugarriak herritarren gurarietatik hurbil egongo lirateke, hobeak direlako. Modu horretan, segmentu horietako bakoitzean, lan-eskariarekin lotutako osagaiak (teknologia) eta eskaintzarekin lotutako osagaiak (klase azpikultura) egongo lirateke.

Lehen merkatuaren barruko zatiketa hori dela bide, langileen arteko bereizketak daudela aitor daiteke «ontzat» edo "desiragarritzat» hartutako merkatuaren segmentuaren barruan. Hau da, horri esker, arreta osoa ez da jartzen bigarren mailako merkatuko langile kaltetuenen arazoetan bakarrik; horren ordez, itxuraz segmentu on baten barruan dauden langile batzuek ere desabantailak dituztela ikus daiteke.

Pioreren ustez, bigarren mailako sektorearen eta lehen sektoreko goiko eta beheko segmentuen karakterizazioak iradokitzen ditu literatura soziologikoan beheko klaseko azpikulturaren, langile klasearen eta erdiko klasearen artean egiten diren bereizketen antzekoak. Modu horretan, badirudi lan merkatuaren zatiketak azpikultura horiekin lotuta daudela nahiko argi eta, ziurrenik, azpikultura horiek dituztela oinarri. Betiere, kontuan hartu behar da azpikulturen ezaugarriak gizabanakoaren bizi-zikloan aldatu egiten direla (Piore, 1983b).

Aitzitik, bigarren mailako merkatuek lan-baldintza makurragoak dituzte, barne sustapenerako aukera handirik gabe, eta soldata txikiak dira nagusi. Kutunkeria eta laneskuaren txandaketa handia nabarmenak izaten dira, eta modu horretan, enpleguaren ezegonkortasuna sustatzen da. Faktore horiek guztiak ez dira batere mesedegarriak enpresaren barruan produktibitate eta lehiakortasun maila handiak eskuratzeko. Bigarren mailako merkatu horietako laneskua, egoera koiuntural arruntetan, behe klasekotzat hartzen da.

Lan-merkatuaren barruan lehen mailako merkatua eta bigarren mailako merkatua bereizteak lanpostuari eta enpresaren barruan langilearen sustapenari lotuta dagoen gizarte-estratifikazioa erakusten du. Hala ere, lanean mugikortasunik ez izatea ez da behar den besteko baldintza segmentuak esistitzeko, Tohariak (1983:24) gogorarazten duen bezala; modu berean, gizarte-mugikortasunik ez izatea ez da baldintza gizarte-klaseak esistitzeko; gizarte-klase horiei Schumpeter-ek beti jende desberdinak okupatutako autobusei 
buruz egiten duen metafora aplikatu ahal zaie. Egile horren arabera, autobusak (gizarteklaseak) esistitzen dira autobusak egiten dituen geldialdietan jende-trukea egon zein ez (goranzko edo beheranzko mugikortasuna). Metafora hori lan-merkatuari eta bertako langileei aplikatzeko modukoa da. Horren arabera, merkatuaren segmentazioa ez da langilearen barne sustapenerako erraztasunaren ondorioa; horren ordez, segmentazioa lanmerkatu horri datxekio, eta horren ondorioz, segmentu bakoitzak ezaugarri jakin batzuk ditu.

Beraz, LMST izenekoak modu arrazoitsuan azaltzen du lan bizitzan dagoen laneratzeko bide bikoitza, bertakoek eta atzerritarrek modu paraleloan egiten dutena. Azken horiek, oro har, merkatuaren beheko zatian soilik egongo dira, zaurgarriagoak direlako. LMST migrazio-prozesu batzuk azaltzeko puzzle teorikoaren piezatzat har daiteke, hala nola Europan joan den mendean eta mende honetan gertatutakoak azaltzeko; izan ere, lan-eskariari (laneskua) lotutako gaiak funtsezkoak izan dira eta izaten jarraitzen dute harrerako lekuetan herritarren joan-etorriak ulertzeko (laneskua). Hori guztiz aplikagarria da Espainian eta Euskadin.

Cachónek (2009) «España inmigrante» izeneko liburuan deskribatzen duen azken hamarkadetako immigrazioa nola sortzen den ulertu ahal izateko, beharrezkoa da hau ulertzea: nazioarteko immigrazioaren jatorria globalizazio-prozesuan dagoen merkatuko ekonomia da, garapen ekonomikoa eta sortzen diren aldaketa politikoak abiapuntu hartuta (Mundu Sistemaren Teoria); nazio zentralen garapen industria ostekoak bikoizketa sortzen du lan-merkatuaren barruan. Modu horretan, bigarren mailako sektore bat sortzen da, eta horretan, enpleguak gaizki ordainduta daude, lan-baldintzak ez dira onak eta sustapena urria da edo ez dago batere sustapenik (LMST). Modu horretako enpleguek langile immigranteak behar dituzte azkenean, eta zuzenean, batzuetan erakartzearen bidez, migrazio-fluxua eragiten dute (LMST), Massey, Arango et al. egileek dioten bezala.

Antzeko zerbait esaten zuen Sassenek (1993:49). Bere esanetan, gizarterik garatuenek atzerriko lan-eskaintzara jotzen dute hazkunde ekonomikoaren uneetan; izan ere, une horietan, gizarte industrialek, bertakoentzat desiragarriak ez diren lanpostuak sortzen dituzte, eta bertakoen asmoak goragokoak izaten dira. Hori dela eta, lanesku atzerritarra behar izaten dute lanpostu horietarako. Fenomeno hori Piorek ere aipatu zuen (1983a:274).

Egindako ikerketak (Garcia Azpuru, 2017) argi eta garbi uzten zuen Espainiako lan-merkatuan zegoen dualtasun hori. Gizarteko kolektiborik zaurgarrienentzat — gazteak, emakumeak eta immigranteak - izaten dira inork nahi ez dituen lanpostuak. Lanpostu horiek bigarren mailako merkatuan eta lehen mailako merkatuko beheko segmentuan kokatuta egoten dira.

Era berean, Europako lan-merkatuaren segmentazioaren analisiarekin jarraituz, esan daiteke, azken hamarkadetan, Europako hegoalderantz egon den lan-migrazio ia osoa se- 
ktore informaleko enplegura bideratu dela (Reyneri, 2001). Hain zuzen ere, sektore hori lan-merkatuko beste segmentu bat da, baina bigarren mailako merkatuak dituen baldintzak baino makurragoak dituena. Izan ere, agintarien eta erakundeen kontroletik kanpoko egoera estra-ofiziala izaten du. Kasu honetan, immigrante gehienek bigarren mailako merkatuko lanpostuak okupatzeaz gain, herrialde hartzaileko ekonomia informalak eskaintzen dituenak okupatzen dituzte. Azken horiek bigarren merkatuko edo segmentuko alderdirik txarrena direla esan daiteke, segmentu guztietako baldintzarik makurrenak dituztenak.

Horren arabera, eta Weber-en hitzak erabiliz (1969:684), «gizabanakoak merkatuan dituen aukerek gizabanako horren patua baldintzatzen dute». Hau da, lan-merkatua segmentatuta dagoela eta immigranteak estratifikatuta daudela onartzen badugu, lan-merkatuko zenbait sektoretan kokatuta, horrek esan nahi du gizabanako horiek erraztasun handiagoa dutela merkatuko nitxo horietan lana aurkitzeko; beraz, Weber-ek esaten duen moduan, logikoa da pentsatzea pertsona batek inguru batean edo bestean izan ditzakeen lan-aukeren arabera hautatuko duela bere jomuga eta garatuko duela bere migrazioproiektua.

Horrela, modu partzialean ondorioztatu daiteke, Espainian herrialdeko ekonomiak behar izan duen immigrazioa jaso dela, herrialdean behar izan den unean, eta hori horrela da, lan-immigraziorako benetako «dei-efektua» baita immigranteek bete ditzaketen lanpostuen eskaintza zabala egotea. Hala aipatzen zen Lan eta Immigrazio Ministerioko Immigrazioaren Behatokiak 2009an egindako txostenean. Modu horretan, oraindik sorlekuko herrialdean dauden immigrante potentzialek jomugan kokatutako gizarte-sarearen mezua jasotzen dute (haien aurretik emigratu zuten familiakoak edo ezagunak): «etorri hona, hemen lana dago eta». "Lan arloko dei» hori ez da migrazio-prozesu bat abiatzeko faktore erabakigarri bakarra. Hala ere, lanerako aukera horiek, Laparrak aipatzen zuen potentzial integratzaile 4 hori, izaten da immigrazioaren hazkundea bultzatzen duen motor nagusia. Baina migrazioak prozesu askoz konplexuagoak dira, eta bestelako faktoreek ere hartzen dute parte, hala nola, familia-, gizarte- eta kultura-arrazoiek. Modu horretan, immigranteen ehuneko baten kasuan, migratzeko erabakian ez du zerikusirik izaten lan egiteko aukerak, Arangok (2003) esaten zuen moduan. Immigrazio-fluxuaren barruan beti egoten dira hari batzuk, eta horien arabera, jomugan lan egiteko aukera ez da migratzailearentzako leitmotiva; hala ere, "gizarte-laguntzen deia» baztertuta geratzen da, hori ez baita behar den besteko faktorea edo arrazoia pertsonen nazioarteko mugimendua eragiteko.

EAEn Espainiako ezaugarrien antzekoak ikus daitezke. Aurretik esandako guztia euskal errealitateari aplikatu ahal zaio. Kasu honetan ere, lan-merkatu segmentatuaren aurrean

\footnotetext{
${ }^{4}$ Potentzial integratzailea: Miguel Laparrak garatutako terminoa. Horren arabera, eskualde bakoitzeko potentzial integratzailearen arabera, horrelakoa izango zen eskualde batean eta bestean kokatutako immigrazioaren osaera.
} 
egongo ginateke, baina berezko ezaugarriekin, Espainiako beste lurralde batzuekin zerikusirik ez dutenak. Lan-merkatuan nekazaritza eta abeltzaintzak eta eraikuntzak pisu gutxi daukate - jarduera horietan egoten da informaltasun mailarik handiena-. Zerbitzuen sektoreak gero eta pisu handiagoa du, eta bertan maila formala eta informala sartzen dira. Modu horretan, gizarte-beharrizanak lanesku-eskariei lotuta egongo lirateke, eta lan-merkatuaren egiturak berak gauza bera egingo luke immigranteen profil batzuekin. Beraz, hor jokoan sartuko litzateke berriro jomugako lan-eskaintzaren eta jasotako immigrazio-fluxuaren arteko lotura. Eskaintza hori atzerritarrentzat ez da oso erakargarria EAEn, baina bai beste autonomia-erkidego batzuetan. Hori dela eta, euskal lurraldean atzerritar gutxiago dago, gizarte-laguntzen arloan Estatuko batezbestekoaren gainetik egon arren.

\section{METODOLOGIA}

Artikulu hau azken zortzi urteetan egindako ikerketa zabalago baten zati bat da. Ikerketa horretan, EAErako migrazio-fluxuak aztertzen dira oro har hartuta.

Kasu honetan, hipotesi moduan hartu dugu EAEra iritsi eta bertan ezartzen den immigrazioa ez datorrela ongizate-estatu bat dagoelako eta inmigrante horiei gizarte-laguntzak eskaintzen dizkielako. Horren ordez, immigrazioa iristeko beste arrazoi batzuk daude, eta lotuago daude jomugako beharrizanei sorlekuko beharrizanei baino (EAEn ere bai).

Ikerketa honetan erabilitako metodologia analisi kuantitatiboaren eta kualitatiboaren arteko konbinazioa izan da.

Alderdi kuantitatiborako, besteak beste, hurrengo hauek eskainitako estatistikak eta datubase instituzionalak erabili ditugu: INE (Estatistika Institutu Nazionala), Ikuspegi (Immigrazioaren Euskal Behatokia), Eusko Jaurlaritzako Enplegu eta Gizarte Gaietako Saila. Hortik autonomia-erkidegoetan bizi diren atzerritarren datuak atera ditugu, eta horietako bakoitzerako, atzerritarren dentsitate demografikoa atera dugu. Tasa horrek erakusten du atzerritarren kolektiboak erkidegoaren barruan duen pisua, eta horri esker ikus daiteke zein autonomia-erkidegok izan ditzaketen zailtasunik handienak gizarte-kohesioan, integrazioan... immigranteek bertan bizi den biztanleria osoarekin alderatuta hartzen duten ehunekoa oinarri hartuta. Horrez gain, atzerritarrek Espainiako eskualdeen arabera duten banaketari buruzko mapa lortu dugu, eta horri esker ikusi ahal izan da zein eskualdetan bizi den immigrante gehien.

Bestalde, alderdi kualitatiboan, nazioarteko migrazio-fluxuetan adituak diren pertsonak identifikatu ditugu ${ }^{5}$, metodo ez-probabilitatezkoa erabiliz. Aditu horiei hamasei elkarrizketa sakon egin zitzaizkien. Alderdi horrek du pisurik handiena artikulu honetan, azter-

\footnotetext{
${ }^{5}$ Ikusi eranskin metodologikoa.
} 
tzen ari garen tematikara gehien lotzen zaiona da eta. Hain zuzen ere, horixe garatuko dugu hurrengo atalean.

Hamasei pertsona horiek migrazioen esparruan dituzten ezagutzengatik eta lan-esperientziarengatik hautatu genituen, bai oro har, bai EAEren kasu zehatzerako. Batzuk politikaren mundukoak dira — hala nola aholkulariak edo erakundeen barruko kargudunak-, beste batzuk arlo akademikokoak eta/edo ikerketen mundukoak dira, eta baten bat enpresa-mundukoa da. Aditu horien profilak zazpigarren atalean jaso ditugu, eranskin metodologikoan.

Bestalde, elkarrizketak bederatzi galdera zituen, denbora aldetik hiru bloketan bildu ahal zirenak. Espainiarako eta Euskadirako immigrazioaren iraganari, orainaldiari eta etorkizunari buruz galdetu genien.

EAEra immigranteak etortzeko arrazoiak eta faktoreak zein diren argitzeko eta tartean jomugako gizarte-laguntzen "dei-efektua» dagoen ikusteko, artikulu honetarako ${ }^{6}$, elkarrizketako lehen eta zortzigarren galderak hartu ditugu, horietan hitz egiten baita atzerritarrak etortzeko faktoreei buruz (galdera horiek hartzen ditu oinarri ondoren egin dugun analisiak). Bi galdera horietan lortutako erantzunek hainbat informazio ematen ziguten erakundeetako datu estatistikoetatik ateratako informazioa osatu ahal izateko.

Hauek izan ziren galderak:

-1. GALDERA. Zure ustez, nola azal daitezke joan den hamarkadan Espainiara iritsi diren migrazioak?

-8. GALDERA. Horren ondorioz, zure ustez, gehiago da «beharrizan-efektua» «deiefektua» baino? («Beharrizan-efektua» izango litzateke atzerritarrak etortzea guk behar ditugulako; eta «dei-efektua» izango litzateke haiek etortzea ikusten dutelako hemen bikain hartuko ditugula, laguntzak izango dituztela...) (Euskadiri dagokionez)

Horrela, lehenengo galderaren bidez, adituek azaltzen zuten haien ustez zergatik iritsi zen immigrazioa Espainiara laurogeiko hamarkadaren amaieratik xxı. mendearen hasierara. Zortzigarren galderaren bidez, EAEko errealitatea gehiago zehaztu ahal zen, eta «deiefektu» hori benetan esistitzen zen ondorioztatu zitekeen; izan ere, argudio hori herritarren artean oso zabalduta zegoen, eta erabat lotzen zitzaien gizarte-laguntzei oro har eta DBEri zehazki.

\footnotetext{
${ }^{6}$ Elkarrizketa osoa Amaia Garcia-Azpururen doktorego-tesia egiteko gauzatu eta ustiatu zen. Tesian analisia askoz zabalagoa zen, eta ez ziren soil-soilik aztertzen gizarte-laguntzak eta migrazioaren gain duten deiefektua.
} 
Elkarrizketak aztertuta, hainbat informazio lortu ahal izan zen. Informazio hori erantzun erkideen arabera multzokatu zen. Kasu batzuetan, aipamenak hitzez hitz jaso ditugu hurrengo atalean, ideiak garatzen ditugun heinean. Kasu horietan, elkarrizketaren barruan aurretik «E» duten zatiak adituen erantzunak dira; aurretik «G» duten zatiak, ordea, elkarrizketatzaileak egindako galderak dira. Era berean, aipamen bakoitzaren amaieran, parentesi artean, «Elk» eta zenbaki bat agertuko da: elkarrizketatutako aditu bakoitzari dagokion elkarrizketa zenbakia adierazten du, eta hori eranskin metodologikoan jaso dugu, artikulu honetan bertan.

Gainera, izaera kuantitatiboa eta kualitatiboa duen metodologia paraleloan eta elkar osatuz erabili denez, mota askotako datuak lortu dira, eta horiek aztertuta, ondorio argiak atera dira Euskadira immigrazioa iristeko dauden benetako faktoreen edo arrazoien inguruan.

Lan honen helburua da beste erreminta bat ematea Euskal Herrira iristen den immigrazioaren inguruko zurrumurruei aurre egiteko. Izan ere, askotan, gizarte-laguntzei eta laguntza horien inguruko gehiegikeriei lotzen zaie immigrazioa.

\section{EMAITZAK}

Egindako azterketaren ondoren atera ziren emaitzetara iristeko, estatistikek eskainitako datuak (analisi kuantitatiboa) eta adituek esandakoak (analisi kualitatiboa) alderatu ziren, metodologiari buruzko aurreko atalean jaso dugun bezala. Modu horretan, datuak eta ekarpenak gurutzatu genituenez, gaur egun nazioarteko migrazioei buruz eskura dagoen informazio guztia erabili ahal izan genuen.

Estatistikak eta datu-baseak aztertuta, ikusten genuen Espainian bilakaera egon zela munduko migrazio-fluxuen jomuga moduan azken bi hamarkadetan. Hala ere, autonomia-erkidegoen artean aldea zegoen herrialdera iristen ziren pertsona horien banaketari erreparatuz gero.

2000. urtean, Espainian 923.879 atzerritar bizi ziren, 2010ean 5.747.734, eta 2017ko urtarrilaren 1eko behin-behineko datuen arabera, 4.549.8587. Bilakaera hori herrialdeko autonomia-erkidego guztietan ikusten zen, baina horietako bakoitzean, immigranteen banaketa eta agerpena desberdina zen, 4.1. eta 4.2 tauletan ikus daitekeen moduan.

\footnotetext{
7 Datuak: INE, Estadística del Padrón Continuo.
} 
4.1. taula. Espainian bizi diren atzerritarren banaketa autonomia-erkidegoen arabera (kopurua eta ehunekoa). 2017/01/01eko behin-behineko datuak

\begin{tabular}{lrr} 
ESPAINIA OSOA & 4.549 .858 & \\
\hline ANDALUZIA & 599.879 & $\% 13,2$ \\
ARAGOI & 132.134 & $\% 2,9$ \\
ASTURIASKO PRINTZERRIA & 38.798 & $\% 0,9$ \\
BALEAR UHARTEAK & 186.340 & $\% 4,1$ \\
KANARIAK & 245.821 & $\% 5,4$ \\
KANTABRIA & 29.388 & $\% 0,6$ \\
GAZTELA ETA LEON & 121.536 & $\% 2,7$ \\
GAZTELA-MANTXA & 160.815 & $\% 3,5$ \\
KATALUNIA & 1.038 .455 & $\% 22,8$ \\
VALENTZLAKO ERKIDEGOA & 636.595 & $\% 14,0$ \\
EXTREMADURA & 31.388 & $\% 0,7$ \\
GALIZIA & 86.881 & $\% 1,9$ \\
MADRILGO ERKIDEGOA & 793.513 & $\% 17,4$ \\
MURTZLAKO ESKUALDEA & 197.737 & $\% 4,3$ \\
NAFARROA & 54.431 & $\% 1,2$ \\
\hline EUSKADI & 142.392 & $\% 3,1$ \\
Araba & 26.500 & $\% 0,6$ \\
Bizkaia & 67.324 & $\% 1,5$ \\
GipuzkOa & 48.568 & $\% 1,1$ \\
\hline ERRIOXA & 34.765 & $\% 0,8$ \\
Ceuta & 5.643 & $\% 0,1$ \\
Melilla & 13.347 & $\% 0,3$
\end{tabular}

Iturria: egileek egina. Datuak: INE, Estadística del Padrón Continuo.

4.2. taula. Espainian bizi diren atzerritarren dentsitate demografikoa autonomia-erkidegoen arabera. (Ehunekoak) 2017/01/01eko behin-behineko datuak

\begin{tabular}{|c|c|c|c|}
\hline & $\begin{array}{c}\text { Herritarrak } \\
\text { guztira }\end{array}$ & $\begin{array}{c}\text { Atzerritarrak } \\
\text { guztira }\end{array}$ & \\
\hline ESPAINIA OSOA & 46.539 .026 & 4.549 .858 & $\% 9,8$ \\
\hline$\overline{\text { ANDALUZLA }}$ & 8.370 .368 & 599.879 & $\% 7,2$ \\
\hline ARAGOI & 1.307 .395 & 132.134 & $\% 10,1$ \\
\hline ASTURLASKO PRINTZERRLA & 1.034 .681 & 38.798 & $\% 3,7$ \\
\hline BALEAR UHARTEAK & 1.115 .255 & 186.340 & $\% 16,7$ \\
\hline KANARIAK & 2.106 .624 & 245.821 & $\% 11,7$ \\
\hline KANTABRLA & 580.140 & 29.388 & $\% 5,1$ \\
\hline GAZTELA ETA LEON & 2.424 .395 & 121.536 & $\% 5,0$ \\
\hline GAZTELA-MANTXA & 2.030 .661 & 160.815 & $\% 7,9$ \\
\hline KATALUNLA & 7.551 .285 & 1.038 .455 & $\% 13,8$ \\
\hline VALENTZIAKO ERKIDEGOA & 4.935 .010 & 636.595 & $\% 12,9$ \\
\hline EXTREMADURA & 1.079 .224 & 31.388 & $\% 2,9$ \\
\hline GALIZIA & 2.707 .700 & 86.881 & $\% 3,2$ \\
\hline MADRILGO ERKIDEGOA & 6.504 .584 & 793.513 & $\% 12,2$ \\
\hline MURTZLAKO ESKUALDEA & 1.469 .656 & 197.737 & $\% 13,5$ \\
\hline NAFARROA & 642.797 & 54.431 & $\% 8,5$ \\
\hline EUSKADI & 2.193 .205 & 142.392 & $\% 6,5$ \\
\hline Araba & 326.373 & 26.500 & $\% 8,1$ \\
\hline Bizkaia & 1.147 .649 & 67.324 & $\% 5,9$ \\
\hline Gipuzkoa & 719.183 & 48.568 & $\% 6,8$ \\
\hline ERRIOXA & 315.009 & 34.765 & $\% 11,0$ \\
\hline Ceuta & 84.959 & 5.643 & $\% 6,6$ \\
\hline Melilla & 86.078 & 13.347 & $\% 15,5$ \\
\hline
\end{tabular}

Iturria: egileek egina. Datuak: INE, Estadística del Padrón Continuo. 
Atzerritarrek Espainiako lurraldean duten banaketari erreparatuz, Espainian bizi diren atzerritarren ehuneko hirurogeita bostetik gora lau autonomia-erkidegotan kokatzen direla ikus daiteke: Katalunia, Madril, Valentzia eta Andaluzia. Euskadi atzerritar egoiliarrak dituen bederatzigarren autonomia-erkidegoa da, Estatuko batezbestekotik behera.

Era berean, immigrazioak herrialdean duen dentsitate demografikoa aztertzen denean, marrazkia esanguratsuagoa da EAEren kasuan, autonomia-erkidego guztien artean hamabigarrena baita. Hau da, EAEko biztanle guztien artean, atzerritarrak \% 6,5 besterik ez dira, Estatuko batezbestekotik askoz ere beherago.

Datu horiek erakusten dute a priori EAE immigrazioa erakartzen duen autonomia-erkidegoa dela pentsatzen den arren, bertan dagoen ongizate-egoera eta/edo gizarte-prestazioak direla-eta, itxuraz argudioa bertan behera utzi behar dela, kolektibo horrek autonomiaerkidegoan duen agerpena oso txikia baita gainerako autonomia-erkidegoekin alderatuz gero. Bestela esanda, esan daiteke immigrazioaren eta gizarte-prestazioaren artean askotan aurresuposatzen den lotura hori ez dela halakoa - komunikabideek asko erabiltzen dute, eta asko entzuten da eztabaida politikoetan zein kalean-. EAEren kasuan, datuek erakusten dute immigrazioa itxuraz ez dagoela hain lotuta gizarte-laguntzekin, edo, bestela esanda, badirudi gizarte-laguntzak ez direla immigranteak EAEra etortzeko motorra edo faktore nagusia.

Elkarrizketatutako aditu guztiek ere ideia hori garbi utzi dute. Beste faktore edo arrazoi batzuk aipatzen zituzten EAEra atzerritarrak iritsi eta bertan kokatzeko. Faktore horiek askotarikoak izan zitezkeen, baina haien artean oso lotuta zeuden. Hala ere, guztiak ados zeuden esatean baztertu egin behar zela Euskadira immigrazioa iristeko faktorea DBE edo bestelako prestazio ekonomiko-soziala zela:

E- Batzuetan, batzuetan dei-efektuarengatik da, baina beste immigrante batzuen deia izaten da. Eta nik uste dut beste immigrante batzuen dei-efektua arrazoi nagusia dela... hau da, itxaropena eskaintzen duen herrialde bat izateaz gain, benetako dei-efektua beste immigranteek egiten dute: etorri hona, hemen lana dago eta. Eta hori bizi izan dugu... immigrazio handia, Euskadirako immigrazioa, barrukoa, dei-efektuaren bidez bizi izan dugu. [...] (Elk9)

E- [...] krisiaren aurretik, \% 95-90 atzerritik Euskadira zuzenean etortzen zen, eta \% 10 beste autonomia-erkidego batzuetatik iristen zen. Eta, krisiaren garaian, \% 50-60 atzerritik dator zuzenean, eta \% 40-50 beste autonomia-erkidego batzuetatik dator. E... eta zergatik dator beste autonomia-erkidego batetik.? Beste autonomia-erkidego batetik dator, hemen, Euskadin, langabezia gutxi dagoelako, eta ongizate-sistema.... e... indartsuagoa dagoelako, baina batez ere, autonomia-erkidegoak eta migrazio-kateak daudelako. Orduan, horrek azaltzen du... Eta, aldi berean, batez ere Hego Amerikako jendearentzat, zerbitzuen sektoreak lana ematen jarraitzen du. (Elk4) 
Berdin dio hitzez hitz edo modu leunagoan adierazten badugu, gizarte-sarearen edo migrazio-kateen terminoa erabiliz. Azken finean, «beste immigrante» batzuek deitzen dituzte immigrante berriak. Beraz, immigranteen gizarte-sareek egiten diete "dei-efektu» hori beste immigrante potentzial batzuei. Baina faktore horrek, «gizarte-sareak», ez du bakarrik lan egiten. Gizarte-sare hori sorlekuaren eta jomugaren arteko lokarria da, eta informazioa transmititzen du immigrante potentzialak jomugan aurki ditzakeen benetako aukerei eta aukera potentzialei buruz.

Beraz, gizarte-sarearen faktore hori beste faktore batzuekin osa daiteke, hala nola: sorlekuan baino hobeto bizitzea, langabezia gutxiago edo lan-aukerak. Era berean, zeharka, ongizate-estatua — gizarte-laguntzak - egotea ere aipa daiteke, laguntza edo osagarri moduan, baina inoiz ez migratzeko erabakiaren faktore nagusi moduan. Ideia hori adituek ere azpimarratzen dute. Adituen arabera, ongizate-estatua Euskadira iristeko faktore bat da, baina beti anekdota moduan aipatuta, eta ia beti Espainiako beste autonomia-erkidego batzuetan bizi ziren atzerritarrei lotuta, ez sorlekuko herrialdeetatik zetozenei lotuta. Hau da, kasu horretan, eskualdeen arteko edo nazioaren barruko birremigrazioa zen, hasieran hartu zituen autonomia-erkidegoan lana galtzearen ondorioz ziurrenik. Kasu horretan, prestazioak jasotzeko aukera zegoenez eta EAEn langabezia-tasa txikia zenez, atzerritarrek EAEra etortzea erabaki zezaketen. Modu horretan, esaten zen EAEk Espainiaren barruan nabarmentzeko pisua zuela gizarte-laguntzengatik batez ere azken hamar urteetan bizitako krisi ekonomiko-finantzarioa dela eta. Hala ere, laguntza horiek nolabait beste autonomia-erkidego batzuetatik migrazio-mugimenduak erakartzeko gai diren arren, ez dute hala jokatzen sorlekutik datozen atzerritarrekin. Modu horretan, egon dauden laguntzak nazioarteko migrazio-fluxuak Euskadira bideratzeko motorra eta faktore nagusia direla dioen argudioa baztertuta geratzen da, eta horren ordez, lan-merkatuari dagokion faktorea aipatzen da. Beraz, enplegua da EAEra edo Espainiara iristen den immigrantearentzako faktore erabakigarria. Ideia hori bera dute elkarrizketatutako adituek. Berriro ere, adituek autonomia-erkidegoak dituen lan-aukerak aipatzen dituzte, eta haien ustez, faktore hori erabakigarria da fluxuak eta jomugak lotzeko.

G- Modu horretan, ulertzen dut zuk ez duzula dei-efektuaren ideiarekin bat egiten: gure ongizatea, horregatik etortzen dira Euskadira, gizarte-laguntzengatik, DBE, ez dakit zer...

E- Ez. Esandako guztiaren ostean, nabarmena da nik uste dudala dei-efektu nagusia edo beharrizan-efektua lan-merkatua dela, maiuskulaz idatzita. Ongialdi ekonomikoan nabarmena da hori. Baina gaur egungo krisialdian? Beno, badirudi ez dela dei-efektua izan, datuei erreparatuz gero. Horrek esan nahi du ez daudela, nik esaten dudan moduan, dei-efektutxuak?, edo dei-efektuak minuskulaz idatzita? Ez. Eta egon dira DBErekin, eta nik uste dut nabarmenago, adibidez, Gipuzkoako DBLrekin, azken egun hauetan horrenbeste eztabaidatu dena. [...] Baina nik bai uste dut gizarte-politikek geratze-efektuak eragiten dituztela [...], alderdi positibotik begiratuta. Hau da, dramatikoa izango litzateke atzeraldi ekonomikoa dela-eta lanesku immigranteetatik deskapitaliza- 
tuko bagina, behar izango ditugu eta. (Elk10)

E- Beste mito batzuk hankaz gora jartzeko. [...] Nik Almerian Magrebeko herritarrei elkarrizketak egin nizkien. Euskaditik zetozen, eta nik, noski, nik esan nien: baina zergatik duzue nahiago Ejidon egotea? Plastiko artean, plastiko azpian bizitzen, eta ez ekonomia hondoratu gutxiago duen erkidegoan, guztia erregularragoa duen herrialdean eta gizarte-laguntzak dituen erkidegoan...? Eta erantzuten zidaten: bada, han ez dago lanik edo irregularra naiz eta ez daukat inolako aukerarik, eta hemen, aldiz, gaur ez dut lanik egiten, baina bihar bai. Hau da, bizirik irauteko aukera gehiago ditut. Eta horrek erakusten du immigrantea lan bila datorrela, eta ez gizarte-laguntzen kontura bizitzera. [...] Baina, Diru-sarrerak Bermatzeko Errenta dagoelako etorri direla? Ez. (Elk15)

E- Ez, ez dago inolako efekturik. Nolabait esanda, dei-efektua laneskuaren beharrizan-efektua da. Puntu. Horixe da dei-efektu nagusia: laneskuaren beharra. (Elk14)

Euskadin, nabarmentzen den immigrazioa ekonomikoa da. Lan egiteko adinean dauden eta jarduera-tasa handiak dituzten pertsonen ehunekoa oso handia da, bertako biztanleen ehunekoaren gainetik. Bertako biztanleen jarduera-tasa txikiagoa da (\% 54,94 bertako herritarrak, eta \% 74,98 atzerritarrak), eta zahartze demografikoa ere nabarmena da (euskal biztanleriaren artean, \% 63 lan egiteko adinean dago; atzerriko herritarren kasuan, aldiz, $\%$ 82) $^{8}$. Beraz, atzerritarren adin-profil hori oso adierazgarria da, lan egiteko asmoarekin etortzen direla erakusten baitu. Bertako herritarren kasuan ere, adin-profilak argi erakusten du artatu beharreko gizarte-beharrizan handiak daudela.

Lan-aukerei buruz hitz egin daiteke zuzenean; jomugako beharrizana eta bertako demografiaren ezaugarriak aipa daitezke. Baina gai berari buruz hitz egiteko modu desberdinak besterik ez dira: leku jakin batek lan merkatuan sartzeko eskaintzen dituen aukerak. Kasu honetan, EAEk.

Modu horretan, lan-merkatuan atzerriko pertsonentzako lekua dagoen bitartean, atzerritarrak jomuga horietara joango dira. Horixe da atzerritarrak EAEn beste autonomia-erkidego batzuetan baino gutxiago egotearen arrazoia, autonomia-erkidego honetan lanegonkortasun handiagoa eta beste leku batzuetan baino gizarte-laguntza gehiago egon arren. Badirudi atzerritarrek zailtasun gehiago dituztela EAEko lan-merkatuan sartzeko, merkatua ez delako horren porotsua eta informaltasun gutxiago daukalako. Hori dela eta, EAE ez da jomuga erakargarria Espainiara iristen diren atzerritar gehienentzat.

Bestalde, datu estatistikoek migrazio-fluxuen eta ziklo ekonomikoaren arteko lotura erakusten zuten. Modu horretan, ikusten zen ziklo hedagarria zegoen aldietan, lan-merka-

\footnotetext{
8 Datuak guk atera ditugu INEren Estadística del Padrón Continuo txostenaren 2017ko urtarrilaren 1eko behin-behineko datuak oinarri hartuta, adin tarteen araberako herritarrei dagozkien datuen kasuan; eta Biztanleria Aktiboaren Inkestatik (INE) ateratako 2017ko lehen hiruhilekoko datuak erabiliz, jarduera-tasen kasuan.
} 
tuak lanesku asko eskatzen zuenean, immigrazio-fluxua handitu egiten zela beste urte batzuekin alderatuz gero; beste horrenbeste gertatzen zen krisialdietan eta atzeraldietan: lan-merkatua uzkurtzen zenez, fluxuak gelditu egiten ziren. Are gehiago, EAEra beste autonomia-erkidego batzuetara baino geroago iritsi zen krisialdia, eta horrek argi erakusten zuen immigranteak etortzearen eta lan-merkatuaren artean zegoen lotura. Izan ere, EAEko merkatura krisia iritsi zen arte, atzerritarren fluxua handitu egin zen. Beraz, azken bi hamarkadetan ziklo ekonomiko oso bat ikusi ahal izan dugu, hazkunde-fasea, atzeraldia eta berrekuratzea; eta fase bakoitzean, ikusi dugu eskualde bakoitzeko lan-merkatuaren portaerak atzerritarrak iristea baldintzatzen zuela. Horrela ondorioztatzen zen lotura positiboa edo zuzena zegoela lan-merkatuaren - enplegu-eskaintza - eta migrazio-fluxuen artean, 4.1. eta 4.2. grafikoek jasotzen duten moduan. Hala ere, bertako biztanleek lotura hori beti ez dute argi antzematen.

4.1. grafikoa. EAEn bizi diren atzerriko immigranteen bilakaera, 1998-2016, zenbaki absolutuetan

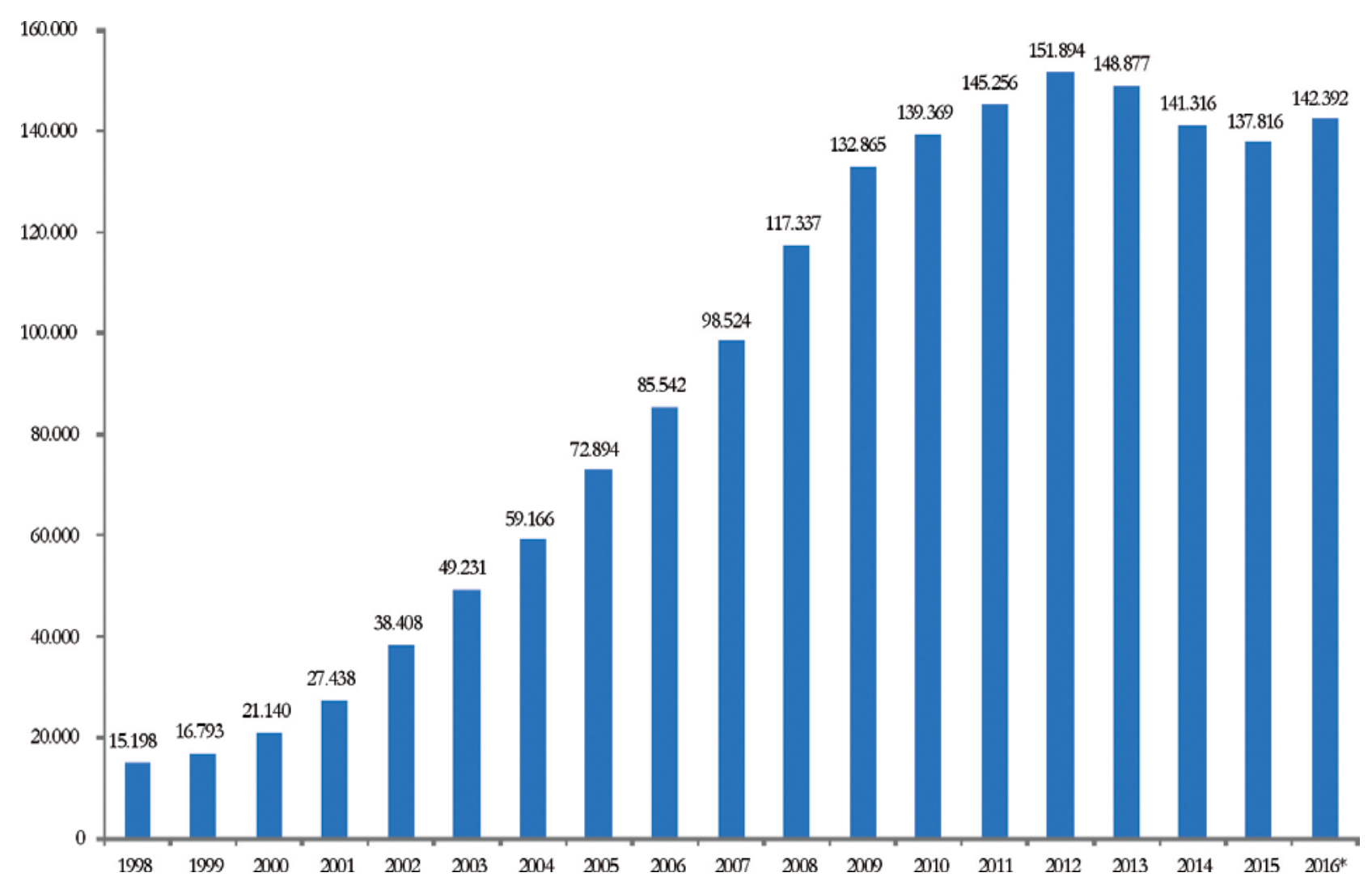

Oro har, immigrazioari buruz hitz egiten denean, immigrazio ekonomikoari buruz ari gara, horixe baita herrialde honetan agerpenik handiena izan duena eta gaur egun agerpenik handiena duena. Sorlekuan zenbait beharrizan dituen immigrazioa da, jomugan izan ditzakeen aukerak baino baldintza makurragoetan bizi den immigrazioa. Pertsona horiek, kasu askotan, beharrizan ekonomikoak zituzten, eta hori dela eta, pentsa zitekeen jomugan laguntza ekonomikoak zeudelako etortzen zirela, baina, egiatan, bestelako arrazoiengatik iristen ziren. Modu horretan, gizarte-laguntzak ez ziren erabakigarriak jomugara iristeko, baina bai bertan eskaintzen zitzaizkien lan-aukerak. 
4.2 grafikoa. Espainian eta EAEn bizi diren atzerriko immigranteen bilakaera, 1998-2016, ehunekoetan

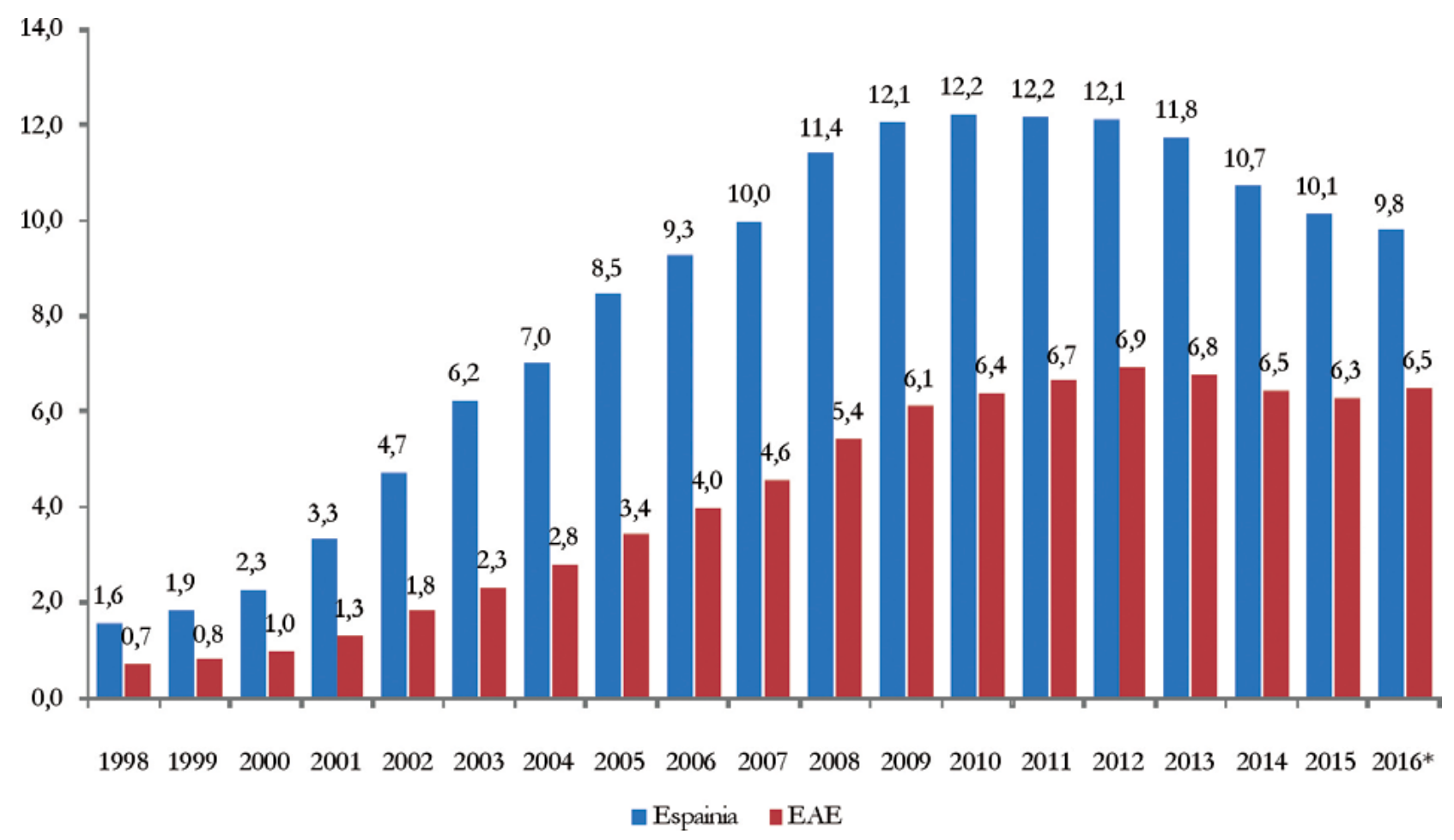

(*) 2016ko datuak 2017ko urtarrilaren 1ean zeuden behin-behineko datuei buruzkoak dira.

Iturria: egileek egina. INEko datuak.

Adituetako batek bakarrik hitz egin zuen bestelako ikuspuntu batetik: «talentudun» immigrazioa, profil profesional handikoa, baliabide ekonomikoekin, baita sorlekuan ere. Kasu horretan, eta immigranteak profil desberdina izan arren, bi alderdiek zuten beharrizana agertzen zen - jasotzen duenarena eta iristen denarena-, migrazio-proiektu horren aurrean, baina, jakina, aurretik azaldutako testuinguruaz bestelakoan. Kasu honetan, immigranteak errendimendu handiko ibilbide profesionalean bilakatzen jarraitzeko beharrizana duela esango genuke, eta jomugako sektore teknologikoetako enpresek profil horiek behar dituztela. Modu horretan, immigrante potentzialak bilatzen duena da maila oso handietan edo teknologikoki oso aurreratuta daudenetan garatu ahal izatea; eta immigrante horren bila ari denak - jomuga - langileen profil oso zehatz bat behar du eginkizun jakin bat egiteko, betiere, berrikuntzaren, ikerketaren, teknologia berrien edo maila handiko ezagutzaren arloetan.

E- A, ez, ez. Deia hau da niretzat, eta erakutsi ahal dizut: Hanburgora goaz profesionalen bila, edo Frantziako Tolosara, aeronautikaren sektoreak esan baitigu profilak behar dituztela, eta Tolosara goaz.

G- Hau da, beharrizan-efektua gure aldetik, adibidez, edo efektu bat guk deitzen diogulako, beharrizan hori daukagu eta.

E- Edo Deustuko Unibertsitateak edo EHUk programa bat daukatelako eta Marie Curie bat behar dutelako, eta nahitaez horrenbeste eta horrenbeste bidali behar dituelako... [...] Deitu nahi duzun bezala. Bi gauzak egin behar dituzu: beharrizana eta deia. 
G- Baina ez da horrenbeste haiek beharrizana izatea haien lana izateko...

E- Ez, ez.

G- Edo haiek entzun dutela hemen bikain bizi garela...

E- Ez, ez. [...] Gainera, jende horrek normalean berdin-berdin egin ahal izango luke lan haien herrialdean, baina mugitu egin behar du egunean egoteko, gaitasunari eusteko, edo... (Elk14)

Aurrekoari jarraituz, guztiz frogatuta dago EAEra iristen den immigrantearen profila gorabehera, gizarte-prestazioak edo laguntzak inola ere ez direla faktore erabakigarria migrazio-proiektu bat hasteko edo jomuga bat hautatzeko.

Gizarte-estaldura horiek bizirik irauteko osagaitzat uler daitezke, eta horien eraginez, geratze-efektua sor daiteke dagoeneko lurraldean edo Espainiko beste eskualde batean dagoen migrazioan - hala adierazten zuen 10. elkarrizketatuak-. EAEko DBE dela-eta asko eta asko idatzi da azken urreetan, baina adituek ez dute uste EAEra immigrazioa iristeko faktore erabakigarria denik. Adituen esanetan, jomugan kokatutako gizarte-sareak gidariak dira, eta fluxuak bideratzen dituzte. Fluxu horiek eskualde bakoitzeko lan-aukera potentzialei erreparatzen diete, aipatutako gizarte-sareek, komunikabideek eta teknologia berriek emandako informazioaren arabera. Azken horiek, aldi berean, migante potentzialari jomugako errealitatea hurbildu diote.

Azken finean, ikerketan jasotako informazioa oinarri hartuta ondorioztatu daiteke beharrizana migrazioaren motorra dela. Noren beharrizana den zehazterakoan bat ez-etortzeak egon daitezke, baina, oro har, esaten da Espainiako eta/edo EAEko lan-merkatuaren eta gizartearen beharrizana dela, laneskua eskatzen baitu, eta immigrantea beharrizan horri erantzutera iristen dela. EAEra immigranteak iristearen ikuspegia aldatu egin da orain: orain beharrizanei buruz hitz egiten da, ez laguntzei buruz; jomugan migrante potentzialak dituen lan-aukerei buruz, ez egon dauden gizarte-prestazioei edo horiek eskuratzeko aukerei buruz (DBE, Osakidetza...).

Datuak eta adituen iritzia ikusita, esan dezakegu immigrantearen eginkizun nagusia jomugan beharrizan batzuei erantzutea dela. Bestela esanda, jomugan beharrizan batzuk daude ezaugarri soziodemografikoekin eta lan-merkatuaren egiturekin lotuta, eta immigranteak, beharrizan horietakoren bati erantzuteko dituen aukerak kontuan haruta, jomuga batera edo bestera joatea erabakiko du. Askotan, informazio hori aurretik jomugan kokatutako gizarte-sareak eta/edo komunikabideek ematen dute. Jomugako lan-aukeren eta migrante potentzialaren arteko lotura-kanalak; edo, bestela esanda, lan-merkatuaren eta leku horretan kokatutako migrazio-osaeraren artekoak. Euskal lurraldean gertatzen den bezala. 


\section{ONDORIOAK}

Zenbat eta heterogeneoagoa eta anizkunagoa den gizarteak gero eta diziplina gehiago barruan hartzen dituzten ikasketak behar ditu. Soziologiak ekonomia behar du, eta ekonomiak giza zientziak, filologia, kimika eta beste ezagutza arlo batzuk behar ditu. Puzzlearen pieza guztiak kontuan hartzen ez badira, litekeena da gero eta dinamikoagoa den errealitatearen interpretazioak agian egokienak ez izatea.

Ikerketa honetan, EAEra immigrazioa iristeari mesede egin ahal dieten faktoreetara hurbilpen txiki bat egin dugu. Hala ere, azterketa hau askotariko adierazleekin osatu beharra dago.

Hala ere, lortutako datuak ikusita, emaitzei begira jarriz, EAEra duela bi hamarkadatik atzerritarrek iristen jarraitzen dutela ikus daiteke, baina Espainiako batezbestekoaren azpitik, ehunekoei zein bolumenari dagokienez.

Behin eta berriro gizarte-prestazioei buruz hitz egiten da. Hala ere, datu estatistikoek eta adituek beste erralitate bat erakusten digute: «dei-efektu» nagusia lan-merkatua edo gizarte hartzailearen beharrizanak dira. Bestela esanda, jomugan lor ditzaketen gizartelaguntzak ez dira erabakigarriak pertsona horiek migrazio-proiektua jomuga jakin batera bideratzeko; horren ordez, jomugako aukerak — batez ere lan arloan - erakartzen dituzte immigranteak, modu lausoan edo argi eta garbi. Aukera horiek dira nazioarteko migrazio-fluxuen motorra eta faktore nagusia. Hori ulertuta soilik azal daiteke Espainian duela bi hamarkadatik gertatzen dena eta EAEk immigrazioaren esparruan izan duen bilakaera. Herrialde osoak eta autonomia-erkidego honek zehazki ikusi dute hazkunde ekonomikoaren aldietan geratzeko asmoa zeukaten immigrante asko iristen zirela, eta atzeraldiko uneetan, fluxua nolabait eten egiten zela. Nola edo hala, fluxuak autoarautu egiten dira, jomugako egoeraren arabera, atzeraldian gizarte-laguntzek apurka-apurka gora egin ahal izaten duten arren. Eta, hala ere, hori gertatu denean, atzerritarren kopuruak ez du gora egin. EAEren kasuak hala erakusten du. Gure autonomia-erkidegoko prestazio ekonomikoak Estatuko batezbestekoaren gainetik daude, eta, hala ere, immigrazioa batez besteko bolumenaren azpitik dago.

Zernahi gisaz, lan-merkatuaren gorabeherek eragin zuzena dute immigrazioa etortzeko unean.

Ikuspegiren azken barometroen arabera (2016 eta 2017), Latinoamerikako pertsona gehiago iristen ari dira, eta EAEn geratzen ari dira krisialditik aurrera - Nikaraguatik eta Hondurasetik iritsi dira batez ere-. Herrialde horietan, krisia gorabehera, migrazioproiektuak abiatu ziren EAErantz. Era berean aipatzen da Magrebeko eta autonomia-erkidegoan aspalditik ezarrita zeuden Latinoamerikako beste herrialde batzuetako herritarren kopuruak atzeraldian eta krisian gutxitu egin ziren arren, orain gora egiten ari direla, azken bi urteetan egoera ekonomiko eta finantzarioak apurka-apurka hobera egin baitu. 
Berriro ere ondorioztatu daiteke, lan-merkatuaren gorabeherek eta beharrizan soziodemografikoek —eskualdearen ziklo ekonomikoaren fasearekin guztiz lotuta daude- eragin zuzenak izango dituztela atzerritarrak lurralde horretara iristeko. Modu horretan, oparoaldian, lan-eskariak gora egingo du lan-merkatuan zein merkatuaren alderdi informalean, gizartean dauden beharrizanei erantzuteko; krisialdian, aldiz, lan-merkatuaren eskariak behera egiten du, eta gizarte-beharrizanak desagertzen ez diren arren, familien barruan erantzuten ahaleginduko dira, inguruabar ekonomiko hobeei esker hirugarrenak kontratatu ahal diren arte. Horren eraginez, oro har, hazkunde ekonomikoaren aldietan immigrazio gehiago iritsiko da, eta krisialdian eta/edo atzeraldian, immigrazio gutxiago.

Ondorio horiek lortu dituzte hainbat adituk ere, besteak beste, Izquierdo (2002, 2007, 2008, 2011), Aierdi (2006, 2008, 2012a, 2012b, 2014), Moreno (2002, 2011), Pajares (2007, 2008, 2009, 2010) eta Parellak $(2007,2008)$.

Lotura hori egiaztatu ahal izan zen datu estatistikoekin batera Espainian eta EAEn ziklo ekonomikoaren joera nola aldatzen zen ikusita. Horrela ondorioztatu ahal izan zen lotura argia dagoela, baina gizarte hartzaileak ez duela erraz ikusten lan-merkatuaren eta immigrazioa etortzearen arteko lotura hori. Lotura horri esker esan daiteke argi eta garbi ez dagoela «dei-efekturik» EAEko ongizate-estatuaren aldetik. Beraz, ez da egia gizarte-laguntzak imana direla erkidegora migrazio-fluxuak iristeko, EAEn dauden atzerritarren kopuru txikiari erreparatuz gero.

Bestalde, immigrazioa iristerakoan, jomugan dauden beharrizanak guztiz kontuan hartzekoak direla esan behar dugu. Beharrizan horiek immigrante potentzialak lan-merkatuan sartzeko dituen aukerak dira.

EAEra ez dira iristen DBEren edo bestelako laguntzen azenarioa harrapatu nahian. Lanaukerak direla-eta iristen dira. Enzensberger-ek (1992:25) hau esaten zuen: «Inork ez du emigratzen promesaren batek erakarrita ez bada».

Laburbilduz, EAEn DBEk immigrazioa erakartzen duela baieztatu beharrean, ikerketan egindako analisi kuantitatiboari eta kualitatiboari esker, baieztapen hori baztertu egiten dugu, eta meritu hori immigrante potentzialak jomugan izan ditzakeen lan-aukerekin lotzen dugu. Oinarrian, bertako laneskuak estaltzen ez dituen gizarte-beharrizanak eta lan-merkatuaren beharrizanak daude. Beharrizan horiek jomugatik transmititzen dira sorlekura, bai aurretik erkidegoan ezarrita dauden gizarte-sareen eskutik, bai komunikabideen eta teknologiaren bidez. Horiek guztiek beharrezko informazio guztia ematen diete immigranteei -batzuetan, azken bi horien kasuan, apur bat aldatuta egon daiteke-, eta horren arabera erabaki ahal dute immigranteek zein den haien profilak izan dezakeen jomugarik onena.

Azken finean, eta "dei-efektuari» buruz hitz egin nahi badugu, EAEko lan-merkatuaren beharrizanak hartu behar ditugu oinarri, eta ez gizarte-prestazioei lotutako gaiak. Izan ere, azken horiek itxuraz ez dira oinarrizko faktorea atzerriko pertsonak gurera etortzeko. 


\section{BIBLIOGRAFIA-AIPAMENAK}

Aierdi Urraza, X. (2006). Población extranjera. En Informe Socioeconómico de la C.A. de Euskadi 2006 (38-91. or.). Vitoria-Gasteiz: EUSTAT.

- Basabe, N., Blanco, C. eta Oleaga, J.A. (2008). Población latinoamericana en la CAPV 2007. Bilbo: Ikuspegi-Immigrazioaren Euskal Behatokia.(2012a) Población extranjera. En Informe Socioeconómico de la C.A. de Euskadi 2006 (47-86. or.). Vitoria-Gasteiz: EUSTAT.

—Oleaga, J.A. et al. (2012b). Atzerriko emakume etorkinak EAen. Gasteiz: EMAKUNDE-Emakumearen Euskal Erakundea.

— eta Fouassier, M. (2014). Mujeres inmigrantes en la CAE. En Blanco, C. (koord.), Movilidad humana y diversidad social en un contexto de crisis económica internacional (175-204. or.). Madril: Trotta.

Arango, J. (1985). Las «leyes de las migraciones» de E. G. Ravenstein, cien años después. Revista Española de Investigaciones Sociológicas, 32. zk., 7-26. or.

- (2003). Migración y Desarrollo. Explicación teórica de las migraciones: luz y sombra. Migración y desarrollo, 1. zk., 4-22. or.

Cachón, L. (2009). La España inmigrante: marco discriminatorio, mercado de trabajo y políticas de integración. Rubí (Bartzelona): Anthropos.

Colectivo IOÉ:

— Actis, W., De Prada, M.Á. eta Pereda, C. (1998). Inmigrantes, trabajadores, ciudadanos: Una visión de las migraciones desde España. Valentzia: Patronat Sud-Nord, Universitat de València.

Doeringer, P.B. eta Piore, M.J. 1985[1971]. Mercados internos de trabajo y análisis laboral. Madril: Laneko eta Gizarte Gaietarako Ministerioa (Jatorrizko bertsioa: Doeringer, P. eta Piore, M.J. (1971). Internal Labor Markets and Manpower Analysis. Lexington: D.C. Heath and Co.).

Enzensberger, H.M. (1992). La gran migración. Bartzelona: Anagrama.

Garcia Azpuru, A. (2016). Influencia de los medios de comunicación en la sobrerrepresentación de los flujos migratorios en España. En Herreros, J. eta Mateos, C. (koord.), Del verbo al bit (723-742. or.). Tenerife: Universidad de La Laguna.

- (2017). Casualidad o causalidad de la afluencia inmigratoria en la Comunidad Autónoma de Euskadi, Doktorego-tesia. HEGOA, Bilbo: Universidad del País Vasco / Euskal Herriko Unibertsitatea. 
Hollifield, J.F. (1992). Immigrants, Markets and States: The political economy of postwar Europe. Cambridge: Harvard Univ. Press.

IKUSPEGI-Immigrazioaren Euskal Behatokia (2005). Anuario 2004. Inmigración extranjera en la Comunidad Autónoma del País Vasco. Bilbo: Ikuspegi-Immigrazioaren Behatokia.

- (2008). Barómetro 2007. Percepciones y actitudes hacia la inmigración extranjera. Vitoria-Gasteiz: Eusko Jaurlaritzako Argitalpenen Zerbitzu Nagusia.

-(2009-2016). Barómetro 2008-2015. Percepciones y actitudes hacia la inmigración extranjera. Bilbo-Leioa: Ikuspegi-Immigrazioaren Behatokia.

—(2004-2017). Panorámicas, n. 1-66. Bilbo-Leioa: Ikuspegi-Immigrazioaren Behatokia.

—(2017). Barómetro 2017. Vitoria-Gasteiz: Eusko Jaurlaritzako Argitalpenen Zerbitzu Nagusia.

INE (Estatistika Institutu Nazionala) (2008). Informe Encuesta Nacional de Inmigrantes. (ENI-2007), Documentos de Trabajo. Madril: INE, Lan eta Immigrazio Ministerioa.

- (2014). España en cifras 2013. Catálogo de publicaciones oficiales de la Administración General del Estado. Madril: INE.

Izquierdo Escribano, A. (2002). Panorama de la migración en España al alba del siglo xxı. En Centro Pignatelli, Seminario de Investigación para la Paz (koord.) eta Alemany, J.M. (egil.), La inmigración, una realidad en España (105-128. or.). Zaragoza: Aragoiko Diputazioa, Kultura eta Turismo Departamentua.

- (2007). Panorama de la inmigración en la España del 2006. En Domínguez, R. (koord.), Inmigración: crecimiento económico e integración social (77-100. or.). Kantabria: Kantabriako Unibertsitatea.

- (2008). En la antesala de la recesión: inmigración y modelo inmigratorio. En Izquierdo, A. (koord.), El modelo de inmigración y los riesgos de exclusión (1776. or.). Madril: Fundación FOESSA, Cáritas Española.

- (2011). La inmigración en España durante la primera década del siglo xxi. En Revilla, M. (koord.), Infancia, juventud y migraciones: una mirada para la cooperación internacional (127-175. or.). Madril: Fundación Carolina: Siglo XXI.

Laparra, M. (2008). La dinámica de la integración social de los inmigrantes y su impacto en la sociedad de acogida. La perspectiva desde Navarra. Política y sociedad, 45. lib., 1. zk., 167-186. or.

Massey, D. S., Arango, J., Hugo, G., Kouaouci, A. eta Pellegrino, A. (1999). Worlds in Motion: Understanding International Migration at the End of the Millennium. Oxford: Clarendon Press. 
Moreno, G., Alonso De Armiño, I., Zubero, I. eta Gómez, I. (2002). Precariedad laboral, precariedad vital. Inguruak: Soziologia eta Zientzia Politikoaren Euskal Aldizkaria-Revista Vasca de Sociología y Ciencia Política, 32. zk., 143-186. or.

Moreno Márquez, G. eta Aierdi Urraza, X. (koord.) (2011). Anuario de la Inmigración en el País Vasco 2010. Bilbo: Ikuspegi-Immigrazioaren Euskal Behatokia.

Pajares, M. (2007). Inmigración y mercado de trabajo. Informe 2007. Análisis de datos de España y Cataluña. Madril: Observatorio Permanente de la Inmigración, Laneko eta Gizarte Gaietarako Ministerioa.

- (2008). Inmigración y mercado de trabajo. Informe 2008. Madril: Observatorio Permanente de la Inmigración, Lan eta Immigrazio Ministerioa.

- (2009). Inmigración y mercado de trabajo. Informe 2009. Madril: Observatorio Permanente de la Inmigración, Lan eta Immigrazio Ministerioa.

- (2010). Inmigración y mercado de trabajo. Informe 2010. Madril: Observatorio Permanente de la Inmigración, Lan eta Immigrazio Ministerioa.

Parella, S. (2007). Mujeres inmigrantes en el mercado de trabajo español. La división internacional del trabajo reproductivo. En Diz, I. eta Lois, M.I. (koord.), Mujeres, instituciones y política (361-386. or). Bartzelona: Bellaterra.

- (2008). La integración de la mujer inmigrante desde su incorporación al mercado de trabajo. Temas para el debate, 160. zk., 41-44. or.

Piore, M.J. (1983a).Los trabajadores extranjeros. En Paro e inflación. Perspectivas institucionales y estructurales (273-289. or.). Madril: Alianza.

- (1983b). Notas para una teoría de la estratificación del mercado de trabajo. En Toharia, L., El mercado de trabajo: Teorías y aplicaciones (193-221. or.). Madril: Alianza.

Ravesntein, E.G. (1885). The Laws of Migration.Journal of the Royal Statistical Society, 48. lib., 2. zk., 167-227. or.; (1889) 52. lib., 2041-301. or.

Reyneri, E. eta Baganha, M. (2001). La inmigración en los países del sur de Europa y su inserción en la economía informal. En Solé, C. (koord.), El impacto de la inmigración en la economía y en la sociedad receptora (53-211. or.). Bartzelona: Anthropos.

Sassen, S. (1993). La movilidad del trabajo y del capital. Un estudio de la corriente internacional de la inversión y del trabajo. Madril: Laneko eta Gizarte Gaietarako Ministerioa.

Toharia, L. (1983). El mercado de trabajo: teorías y aplicaciones. Compilación e introducción de Luis Toharia. Madril: Alianza Editorial.

Weber, M. (1969). Economía y sociedad. Esbozo de sociología comprensiva. Mexiko: FCE. 
INGURUAK [63] | 2017 | 95-118

\section{Metodologia-eranskina}

\section{4. elkarrizketa (Elk4): Arkaitz Fullaondo}

Gaur egun, Euskal Herriko Unibertsitateko dekanordea, Soziologia eta Gizarte Lan Saileko irakaslea eta Ikuspegiko ikerlaria da. Soziologiako lizentziaduna da, eta doktorea Kataluniako Unibertsitate Politeknikoan. Hauek dira berak landutako ikerketa-arloak: gizartebazterketa, etxebizitza eta hirigintza.

\section{9. elkarrizketa (Elk9): María Luisa Setién}

Deustuko Unibertsitateko irakasle emeritua, eta unibertsitate horretako Gizarte Laneko Unibertsitate Eskolako zuzendaria sorreratik, 14 urtez. 2004tik 2012ra «Retos sociales y culturales en un mundo en transformación» izeneko 23 ikerlariko taldea gidatu zuen. Soziologoa eta Zientzia Politikoetan eta Soziologian doktorea Deustuko Unibertsitatean.

\section{0. elkarrizketa (Elk10): Gorka Moreno}

Ikuspegiko gaur egungo zuzendaria eta Euskal Herriko Unibertsitateko Soziologia eta Gizarte Lan Saileko irakaslea. Soziologian doktorea. Hauek dira berak landutako ikerketa-arloak: gizarte-bazterketa, gizarte-politikak.

\section{4. elkarrizketa (E14): Miguel Ángel Navarro}

ALBOAN Fundazioko ikerketaren eta prestakuntza-proposamenen taldean lan egiten du. GKE horretan, kulturartekotasuna eta koedukazioa jorratzen dira. Espainiako Neuropsikiatria Elkarteko Giza Eskubideen ataleko zuzendaritza-batzordeko kidea da. Psikologiako lizentziaduna UPV/EHUn, eta Nazioarteko Migrazio Garaikideen doktorea Comillasgo Unibertsitate Pontifikalean. Ikerketa-arloak: bereizkeria, gizarte-bazterketa, elkarri lotutako gizarte-identitateak eta indarkeria politiko eta soziala.

\section{5.elkarrizketa (Elk15): Trinidad Vicente}

Deustuko Unibertsitateko irakaslea, Gizarte Laneko graduan eta Emakumeen aurkako Indarkeriaren Masterrean. Ikerlaria, Revista Deusto de Derechos Humanos aldizkariko zuzendaria, zenbait aldizkaritako zuzendaritza-batzordeetako kidea eta ebaluatzailea. Politika Zientzietan eta Soziologian doktorea Deustuko Unibertsitatean. Ikerketa-arloak: aniztasuna, giza eskubideak eta generoa. 